\title{
Sinus Bradycardia and QT Interval Prolongation in West Nile Virus Encephalitis: A Case Report
}

\author{
Mustafa Ajam ${ }^{1}$, Ahmad A. Abu-Heija ${ }^{1}$, Mohamed Shokr ${ }^{2}$, Firas Ajam ${ }^{3}$, Ghulam Saydain ${ }^{1}$ \\ 1. Internal Medicine, Detroit Medical Center - Wayne State University, Detroit, USA 2. Cardiology, Detroit Medical \\ Center - Wayne State University, Detroit, USA 3. Internal Medicine, Jersey Shore University Medical Center, Neptune \\ City, USA
}

Corresponding author: Mustafa Ajam,gm0473@wayne.edu

\begin{abstract}
Cardiac arrhythmias were reported in cases of West Nile Virus (WNV) encephalitis; however, the underlying pathophysiology remains incompletely understood. We present a 67-year-old male with altered mental status, later diagnosed with WNV encephalitis. Hospital course was complicated by progressive sinus bradycardia and corrected QT (QTc) prolongation. These findings persisted despite the absence of classical causes and resolved only after improvement of the underlying encephalitis. After excluding classical causes, autonomic dysfunction is one of the proposed mechanisms behind cardiac arrhythmias in WNV encephalitis. Resolution of arrhythmias is expected after the improvement of underlying encephalitis and should be taken into consideration before proceeding for pacemaker placement or other cardiac intervention. Furthermore, this case highlights the importance of continuous cardiac monitoring in WNV encephalitis patients.
\end{abstract}

Categories: Cardiology, Internal Medicine, Infectious Disease

Keywords: sinus bradycardia, arrhythmia, west nile virus encephalitis

\section{Introduction}

Since its discovery in 1999, West Nile virus (WNV) has been associated with a spectrum of neuroinvasive conditions, including encephalitis, meningitis or acute flaccid paralysis and is the leading cause of viral encephalitis in the United States [1-3].

Received 12/26/2018

Review began 12/30/2018 Review ended 01/01/2019 Published 01/03/2019

๑) Copyright 2019

Ajam et al. This is an open access article distributed under the terms of the Creative Commons Attribution License CC-BY 3.0., which permits unrestricted use, distribution, and reproduction in any medium, provided the original author and source are credited.
Despite an improved understanding of this potentially fatal infection, a wide spectrum of its clinical manifestations is yet to be fully understood. Cardiac arrhythmias, including new-onset atrial fibrillation and atrioventricular (AV) node block, have been reported in WNV infections, especially in cases of WNV encephalitis [4-5]. The exact underlying mechanism remains unclear; however, myocarditis or autonomic dysfunction is the proposed explanation for these observed arrhythmias [6]. We report sinus bradycardia and a prolonged corrected QT (QTc) interval resulting in asystole in a previously healthy patient diagnosed with WNV encephalitis. Our case highlights the possible underlying pathophysiology behind cardiac arrhythmias in WNV encephalitis and the importance of continuous cardiac monitoring in such patients.

\section{Case Presentation}

A 67-year-old male with a history of follicular lymphoma and prostate cancer presented to our hospital with an altered mental status for three days. Physical examination revealed a blood pressure of 146/80 $\mathrm{mmHg}$, a heart rate of 89 beats per minute (BPM), a temperature of $38.4^{\circ} \mathrm{C}\left(101.1{ }^{\circ} \mathrm{F}\right)$, normal heart sounds, an inability to follow commands, absent gag reflex and flaccid paralysis involving both upper and lower extremities in addition to absent reflexes in all four limbs. Electrocardiogram (EKG) on day one (Figure 1) showed a normal sinus rhythm and normal intervals. 


\section{Cureus}

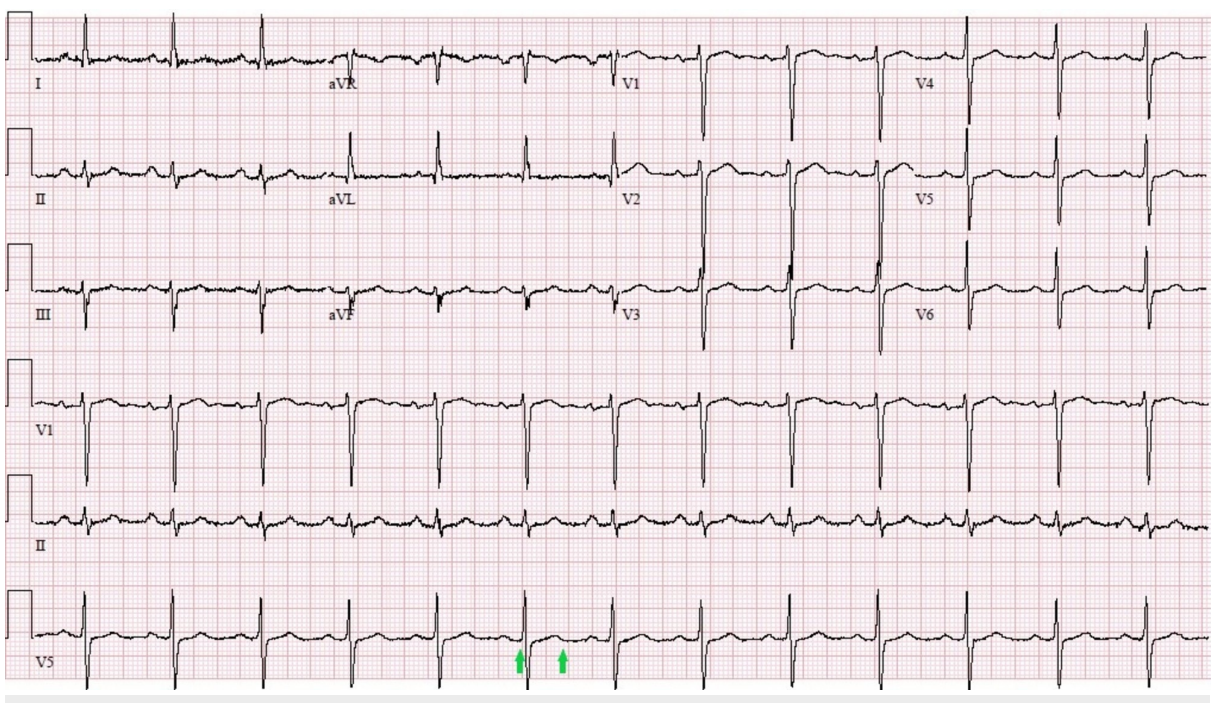

FIGURE 1: Initial EKG on day one showing normal sinus rhythm and normal QTc interval (426 millisecond); indicated between two green arrows

Few hours following admission, his temperature increased to $39.4^{\circ} \mathrm{C}\left(102.9^{\circ} \mathrm{F}\right)$; however, his heart rate remained within the same range at $89 \mathrm{bpm}$. Initial laboratory investigations revealed acute kidney injury with a creatinine level of $3.2 \mathrm{mg} / \mathrm{dL}$ (normal: 0.60-1.20 mg/dL), hypokalemia of $3.2 \mathrm{mEq} / \mathrm{L}$ (normal: 3.5-5.1 $\mathrm{mEq} / \mathrm{L}$ ), hypomagnesemia at $1.7 \mathrm{mg} / \mathrm{dL}$ (normal: $1.9-2.7 \mathrm{mg} / \mathrm{dL}$ ), and elevated creatinine phosphokinase level at 4,082 U/L (normal: 35-350 U/L). No significant acid-base disturbances were noted on arterial blood gas (ABG) analysis. Electrolyte imbalances were corrected within the first 48 hours following admission with fluid resuscitation and electrolyte replacement. Initial troponin level was elevated at $0.2 \mathrm{ng} / \mathrm{mL}$ (normal: $<0.04 \mathrm{ng} / \mathrm{mL}$ ). White blood cell count was normal at 5,300 cells $/ \mu \mathrm{L}$ (normal: $3,500-10,600$ cells $/ \mu \mathrm{L}$ ), with a low lymphocyte count of 600 cells/ $\mu \mathrm{L}$ (normal: 1,000-3,800 cells/ $\mu \mathrm{L}$ ). Head computed tomography (CT) scan did not reveal significant abnormalities. Brain magnetic resonance imaging (MRI) showed small infarcts in the watershed area of deep white cerebral matter. Cerebrospinal fluid (CSF) analysis showed an elevated white cell count of 80 cells $/ \mu \mathrm{L}$ with $57 \%$ neutrophils and $32 \%$ lymphocytes concerning for early viral or bacterial infection. A CSF sample was sent for analysis of WNV immunoglobulin M (IgM) titers, Herpes simplex virus (HSV) polymerase chain reaction (PCR), Epstein Barr virus (EBV) PCR and cytomegalovirus (CMV) PCR. In the meanwhile, intravenous (IV) vancomycin, cefepime, trimethoprim/sulfamethoxazole, and acyclovir were initiated, and the patient was intubated considering his significantly altered mental status and inability to protect his airways.

On hospital day five, telemetry monitoring revealed a gradual downward trend of the patient's heart rate, reaching a nadir of $34 \mathrm{bpm}$. EKG showed sinus bradycardia, first-degree atrioventricular (AV) block and a prolonged QTc interval of $525 \mathrm{~ms}$ (Figure 2).

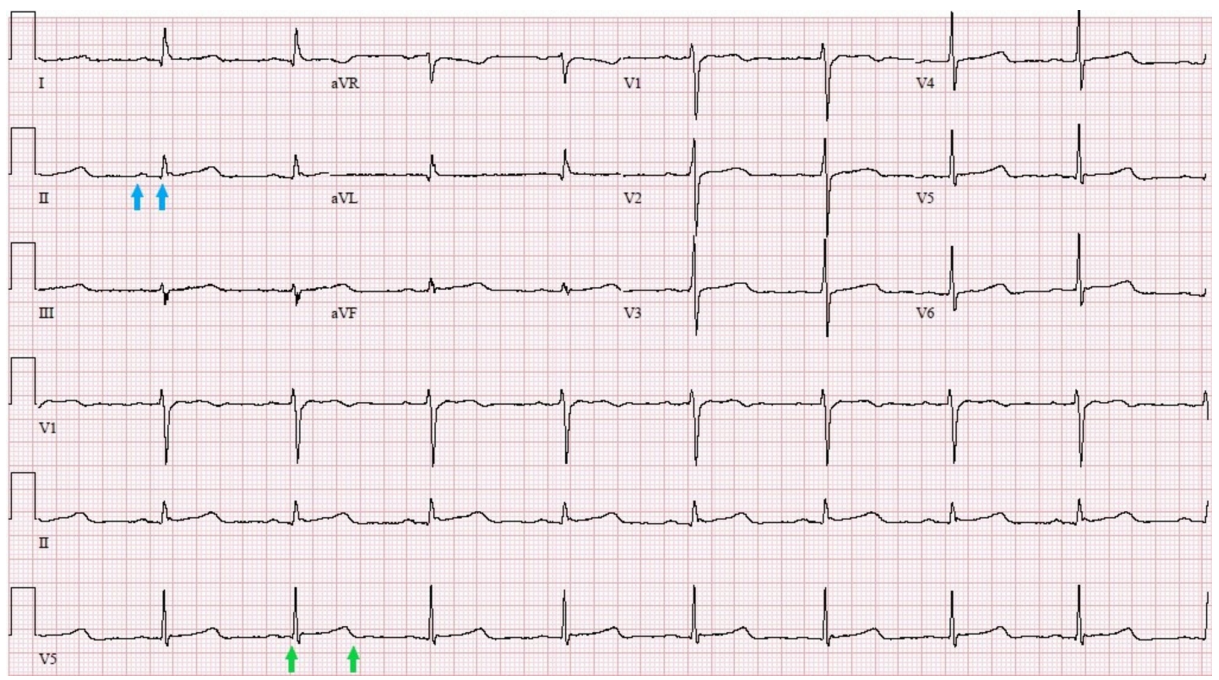

FIGURE 2: EKG on day five showing first-degree AV block (PR interval 
of $240 \mathrm{~ms}$, indicated between two blue arrows) and prolonged QTc of 525 ms (between two green arrows)

EKG: electrocardiogram, AV: atrioventricular, QTc: corrected QT

Later that day, the patient suffered from an episode of pulseless electrical activity (PEA), for which cardiopulmonary resuscitation (CPR) was initiated, achieving a return of spontaneous circulation (ROSC) after 11 minutes. Bradycardia and long QTc persisted despite resolution or electrolyte abnormalities, normalization of troponin levels and absence of hypoxia, acid-base disturbances, atrioventricular blocking, or QTc prolonging medications. Furthermore, EKG did not show any regional wall motion abnormalities or evidence of cardiac ischemia.

Results for the CSF sample that was sent with an initial lumbar puncture on day one showed positive WNV IgM titers and negative results of HSV, EBV and CMV PCR. IV antimicrobials were stopped and IV immunoglobulin (IVIG) was initiated. In the meantime, cardiology team was consulted for further evaluation and possible pacemaker placement. A decision to proceed with supportive care, IVIG treatment, and continuous monitoring was made before considering pacemaker placement. Three days later, his mental status improved, and the sinus bradycardia and the prolonged QT started to gradually improve (Figure 3) and the need for pacemaker placement was deemed unnecessary at this point.

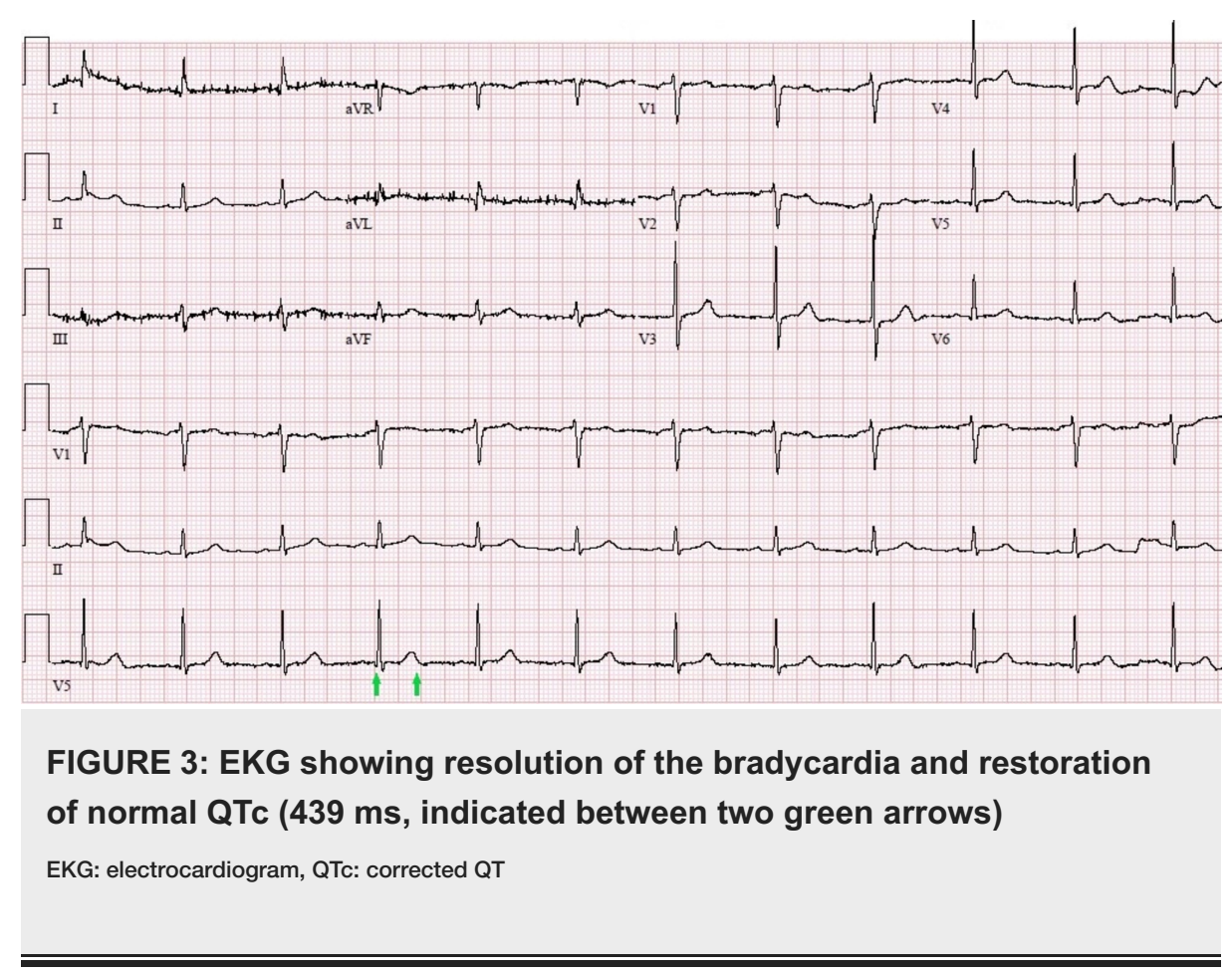

The patient remained in flaccid paralysis and areflexia and could not be weaned off the ventilator. Tracheostomy and percutaneous gastrostomy tube were placed, and the patient was discharged to a skilled nursing home for rehabilitation.

\section{Discussion}

Less than $1 \%$ of cases of WNV infection develop full-blown neuroinvasive disease, presenting with various degrees of neurological involvement, ranging from a mild confusional state to coma and, rarely, even death [2]. In its most severe form, acute flaccid paralysis may develop and can involve diaphragmatic and intercostal muscles leading to respiratory failure [7]. Patients older than 55 years, especially those in an immunocompromised state are at greater risk for neuroinvasive disease [3]. Due to its neurotropism, WNV has a predilection to affect the brainstem structures, especially the medulla and pons, affecting the respiratory and cardiac control centers in that region, leading to various cardiopulmonary complications [2].

Cardiac arrhythmias were described in cases of WNV infections [4-6]. Bode et al. investigated 228 cases of WNV infection in Colorado during 2003 [6]. Cardiac arrhythmias were reported in 7\% of the cases. Arrhythmias were more common in the WNV encephalitis group when compared to WNV meningitis and WNV fever. An array of arrhythmias was noted in this study, including new-onset atrial fibrillation as well as worsening of pre-existing atrial fibrillation, second-degree AV block and third-degree blocks [6]. On the 
other hand, Espinosa et al. reported a case of confirmed WNV encephalomyelitis developing a recurrent idioventricular rhythm requiring permanent pacemaker placement [5]. Kushawaha et al. also reported a patient with WNV encephalitis that developed asystole with resulting death; consequently, autopsy findings revealed evidence of myocarditis secondary to WNV [4]. Table 1 summarizes reported WNV cases associated with cardiac arrhythmia.

\begin{tabular}{|c|c|c|c|c|c|c|c|}
\hline Reference & Case & Initial EKG & $\begin{array}{l}\text { Type of CNS } \\
\text { infection }\end{array}$ & $\begin{array}{l}\text { Type of rhythm } \\
\text { abnormality }\end{array}$ & Echocardiography findings & Presence of myocarditis & Outcome \\
\hline $\begin{array}{l}\text { Kushawaha } \\
\text { et al. [4], } \\
2009\end{array}$ & $\begin{array}{l}65 \\
\text { years, male }\end{array}$ & $\begin{array}{l}\text { Normal } \\
\text { sinus } \\
\text { rhythm }\end{array}$ & Encephalitis & Asystole & $\begin{array}{l}\text { Ejection fraction of } 50 \% \text { to } 55 \% \\
\text { along with impaired left } \\
\text { ventricular relaxation and dilated } \\
\text { left atrium }\end{array}$ & Autopsy confirmed & Death \\
\hline $\begin{array}{l}\text { Espinosa et } \\
\text { al. [5], } \\
2016\end{array}$ & $\begin{array}{l}65 \\
\text { years, male }\end{array}$ & $\begin{array}{l}\text { Sinus } \\
\text { tachycardia }\end{array}$ & Encephalomyelitis & $\begin{array}{l}\text { Idioventricular rhythm } \\
\text { resulting in PEA }\end{array}$ & $\begin{array}{l}\text { Hyperdynamic left ventricle with } \\
\text { an ejection fraction of } 65 \% \text { and } \\
\text { dilated right ventricle }\end{array}$ & Unknown & $\begin{array}{l}\text { Survived after } \\
\text { placement of } \\
\text { a permanent } \\
\text { pacemaker }\end{array}$ \\
\hline $\begin{array}{l}\text { Our case } \\
2018\end{array}$ & $\begin{array}{l}67 \text { years, } \\
\text { male }\end{array}$ & $\begin{array}{l}\text { Normal } \\
\text { sinus } \\
\text { rhythm }\end{array}$ & Encephalomyelitis & $\begin{array}{l}\text { Symptomatic sinus } \\
\text { bradycardia with } \\
\text { prolonged QTc } \\
\text { resulting in PEA }\end{array}$ & $\begin{array}{l}\text { Hyperdynamic left ventricle with } \\
\text { an ejection fraction of } 80 \%\end{array}$ & $\begin{array}{l}\text { Unknown. Cardiac MRl could } \\
\text { not be performed due to } \\
\text { the patient's unstable } \\
\text { condition }\end{array}$ & $\begin{array}{l}\text { Survived without } \\
\text { cardiac } \\
\text { intervention }\end{array}$ \\
\hline $\begin{array}{l}\text { TABLE } \\
\text { arrhyth }\end{array}$ & $\begin{array}{l}\text { 1: Litera } \\
\text { nias }\end{array}$ & Ire revi & еw от repc & ted cases ot v & NV infection assoc & ated with cardia & \\
\hline VV: West & Nile virus, E & KG: electroc & ardiogram, CNS: & central nervous syst & em, MRl: magnetic resonance & maging, PEA: pulseless ele & ctrical activity \\
\hline
\end{tabular}

The exact underlying mechanism behind arrhythmias in WNV virus infection is not well understood. However, the ability of WNV to affect the sympathetic spinal ganglia leading to autonomic nervous system irregularities can play a major role in arrhythmia development [8]. Furthermore, WNV myocarditis is another possible underlying mechanism [4,9]. During the WNV outbreak in Russia in 1999, post-mortem examination of the dead patients revealed WNV myocarditis in 40 cases [9]. However, the total number of deaths was not reported and the percentage of WNV myocarditis among all WNV-related deaths could not be estimated.

In an attempt to expand the literature search criteria, we searched for cardiac arrhythmias in cases of viral encephalitis caused by viruses other than WNV. We found cases of herpes simplex encephalitis associated with cardiac arrhythmias [10-11]. Smith et al. reported a case of sinus node arrest in a patient with herpes simplex encephalitis [10]. Another case of HSV encephalitis presenting with sinus node arrest, attacks of asystole and features of autonomic nervous system abnormalities with labile hypertension, episodic tachycardia, profuse sweating, and hypothermia was also reported by Pollock et al. [11]. Autonomic nervous system abnormalities mediated by the HSV infection were also the proposed mechanism underlying the sinus arrest in both cases [10-11].

Interestingly, our patient also demonstrated another sign of autonomic system involvement, known as pulse-temperature dissociation or relative bradycardia. It refers to an increase in heart rate of less than 10 bpm for every $1{ }^{\circ} \mathrm{F}$ increase in core body temperature. Viruses known to be associated with relative bradycardia include, but are not limited to, WNV, Ebola virus, Flaviviridae, and yellow fever virus [12]. Taking into account the resolution of the relative bradycardia contemporaneously with the recovery of the patient's mental status, we were able to further associate the encephalitis with autonomic dysfunction responsible for the relative bradycardia.

\section{Conclusions}

Although WNV infection primarily affects the central nervous system, cardiac and respiratory complications remain as major contributory factors to mortality in those patients. The mechanism underlying cardiac arrhythmias is not very well understood; however, myocarditis or autonomic abnormalities should be suspected in any case of WNV infection presenting with arrhythmias, especially when other classic causes of arrhythmias are ruled out. Continuous cardiac monitoring is warranted in confirmed or suspected cases of WNV infection, principally in those with a clinical picture of WNV encephalitis. Moreover, the resolution of cardiac arrhythmias in such conditions is expected with the improvement of WNV encephalitis, indicated clinically by improved mental status, which can help avoid unnecessary cardiac interventions such as pacemaker placement. 


\section{Additional Information}

Disclosures

Human subjects: Consent was obtained by all participants in this study. Conflicts of interest: In compliance with the ICMJE uniform disclosure form, all authors declare the following: Payment/services info: All authors have declared that no financial support was received from any organization for the submitted work. Financial relationships: All authors have declared that they have no financial relationships at present or within the previous three years with any organizations that might have an interest in the submitted work. Other relationships: All authors have declared that there are no other relationships or activities that could appear to have influenced the submitted work.

\section{References}

1. Petersen L, Brault A, Nasci R: West Nile virus: review of the literature . JAMA. 2013, 310:308. 10.1001/jama.2013.8042

2. Sejvar J: Clinical manifestations and outcomes of West Nile virus infection. Viruses. 2014, 6:606-623. 10.3390/v6020606

3. Roehrig J: West Nile virus in the united states - a historical perspective . Viruses. 2013, 5:3088-3108. 10.3390/v5123088

4. Kushawaha A, Jadonath S, Mobarakai N: West Nile virus myocarditis causing a fatal arrhythmia: a case report. Cases J. 2009, 2:7147. 10.1186/1757-1626-2-7147

5. Espinosa R, Schelb K: Idioventricular rhythm in a case of West Nile encephalomyelitis . J Neuroinfect Dis. 2016, 7:5-7. 10.4172/2314-7326.1000214

6. Bode AV, Sejvar JJ, Pape WJ, Campbell GL, Marfin AA: West Nile virus disease: a descriptive study of 228 patients hospitalized in a 4-county region of Colorado in 2003. Clin Infect Dis. 2006, 42:1234-1240. 10.1086/503038

7. Hughes JM, Wilson ME, Sejvar JJ: The long-term outcomes of human West Nile virus infection. Clin Infect Dis. 2007, 44:1617-1624. 10.1086/518281

8. Bouffard JP, Riudavets MA, Holman R, Rushing EJ: Neuropathology of the brain and spinal cord in human West Nile virus infection. Clin Neuropathol. 2004, 23:59-61.

9. Platonov AE, Shipulin GA, Shipulina OY, et al.: Outbreak of West Nile virus infection, Volgograd region, Russia, 1999. Emerg Infect Dis. 2001, 7:128-132.

10. Smith BK, Cook MJ, Prior DL: Sinus node arrest secondary to HSV encephalitis. J Clin Neurosci. 2008, 15:1053-1056. 10.1016/j.jocn.2006.06.017

11. Pollock S, Reid H, Klapper P, Metcalfe RA, Ahmed N: Herpes simplex encephalitis presenting as the sick sinus syndrome. J Neurol Neurosurg Psychiatry. 1986, 49:331-332.

12. Mittal J, Estiverne C, Kothari N, Reddi A: Fever and relative bradycardia: a case presentation and review of the literature. Int J Case Rep Short Rev. 2015, 1:4-8. 